\title{
Reforming Education for the Attainment of National Development
}

\author{
Dr. Osamiro Emmanuel OSAGIOBARE \\ Department of Educational Foundations, Faculty of Education, University of Benin, Benin City \\ Victor EKWUKOMA \\ Nigerian Educational Research and Development Council (NERDC), Abuja \\ Evelyn Ofure OBOZOKHAE \\ Department of Educational Foundations, Faculty of Education, University of Benin, Benin City \\ ThankGod Onyebuchi IBE \\ Department of Educational Foundations, Faculty of Education, University of Benin, Benin City
}

\begin{abstract}
No educational system can effectively meet societal needs without regular reforms because the society is dynamic and always in a state of flux. It is in the light of this that this paper examined the need to reform the entirety of the Nigerian educational system. Reforms, which should be an integral part of the entire educational process, make education better, more relevant and accessible to all segments of the population, especially those living in economically disadvantaged areas. As Nigeria matches towards its vision of becoming one of the top 20 economies by 2020 , educational reforms must be a core component of the agenda to adequately provide the needed manpower and intellectual stimulus to drive the envisioned sustainable development. Educational reforms should be drastic and radical for the attainment of quality, pragmatic and functional education by a vast number of Nigerians and for effecting national development in the $21^{\text {st }}$ century Nigeria. The urgent need for Nigeria to join the western world and the emerging Asian countries in scientific breakthroughs cannot be overemphasized. It is only through revolutionary, holistic and radical educational reforms that Nigeria can suitably position itself with a massive opportunity to broaden access to education across wide swathes of the population, and empower the populace with the technical and intellectual skills and stimulus to power Nigeria's transformation and sustainable development. In buttressing these points, this paper examined the concepts of national development and educational reforms. Problems in the Nigerian educational system that call for reforms were $\mathrm{x}$-rayed and suggestions on possible reforms were made.
\end{abstract}

DOI: $10.7176 / \mathrm{JEP} / 10-3-19$

\section{Introduction}

The fundamental role of quality education to national development is beyond question. Education is viewed globally as a veritable instrument for national development. This is because it is seen to be the key to the realisation of individual and societal aspirations. It equips people with requisite knowledge, skills, attitudes, values and competences for the performance of social and economic roles. It confers on the recipients boundless opportunities and expanded life options (Nwadiani and Otakhor, 2011). The former Minister of Education, Professor Ruqayyatu Ahmed Rufai once observed that education is a central part of human capital development of every nation.

The imperative of education in the development of any nation is implicit in its sacred roles of infusing in individuals the necessary skills and competences to drive other sectors of the economy. It is only through pragmatic and functional education that the vast number of unemployed youths in Nigeria can be imbued with self-reliant disposition, the culture of economic independence and job-creating initiatives. It is in this light that Maduka (2008) posited that the link between education and development is not merely contingent, it is necessary and strong. Education and development are practically inseparable. The relevance of education to development is implicated in Fafunwa's (2006) definition of education broadly as all efforts conscious and direct, incidental and indirect, made by a particular society to achieve objectives that are considered desirable with respect to the individuals' personal needs as well as those of the society where the education is based. The principal need of every society is development and it is through the instrumentality of education that this need (development) can be achieved. This is because it is through the medium of education that the various categories of manpower are developed. In turn, the manpower resource transforms the available physical and financial resources to provide the goods and services that eventually bring about economic and national development. Several countries including the United States of America, Japan, Germany, France, The United Kingdom, Italy, Canada, Australia, Spain and South Korea have achieved advanced technological infrastructure through a massive investment in functional education. From the foregoing, it is arguable that Nigeria with an estimated population of over 160 million can only get to her Eldorado through education. That is, it is only through quality education that Nigeria 
can translate all developmental efforts into commendable realities.

\section{The Concepts of National Development and Educational Reforms}

National development can be viewed in terms of growth, changes and improvements that occur in a given society, the aim of which is to enhance the quality of lives of the citizens. Okeke (1990) described national development as a process whereby an economy undergoes social and economic transformation leading to a rise in the standard of leaving for all in terms of health, per-capital income, education, housing, industrialization and other infrastructure.

Educational reforms are actions or recommendations, by those in authorities, that are intended to make education provision better or to put right any fault or errors in the provision of education (Synomwene, 2013).

Reforms maybe regarded as any form of adjustment or improvement in any system or an organisation which may result from definite or deliberate changes which have been effected in the system or the organisation (Musa and Musa, 2007). The two authors further argued that reforms can be engendered in almost all areas of human endeavour. In the education sector, reforms can be accomplished in all the areas from legislations regulating the policies and even to educational standards. There could be radical reforms in the overall philosophy sustaining the objectives and goals of an education system. Similarly, reforms can be effected in the curriculum -from conception to implementation, financing of education, planning, teacher education, pedagogies, staff recruitment process, monitoring and supervision, examination process, admission process, discipline, promotion and staff motivation. One goal of educational reforms is the repositioning of an educational system to meet societal needs and thus, enhance national development. The imperativeness of regular educational reforms is rooted in the dynamism of the society that is invariably in a state of flux.

Implicit in the word 'reform' is dissatisfaction, unwholesomeness and systemic failure. Therefore the clarion call by this paper for holistic and fundamental reforms in the Nigerian educational system is necessarily premised on the undesirable fact that the Nigerian educational system is to all intents and purposes dissatisfactory and fraught with systemic problems. These problems are responsible for the failure of our educational system to accomplish the sacred purpose of education in the Nigerian society as enunciated in the blueprint of the National Policy on Education (1998). Musa and Musa (2007) notably remarked that the policy was philosophically premised on the integration of every Nigerian into our egalitarian society of free citizens who have equal opportunities for an education that will prepare them for effective participation in, and contribution to the developmental programmes of Nigeria.

\section{Problems in the Nigerian Educational System that call for Reforms}

Teaching without learning in Nigerian schools: The principal aim of teaching is learning. A teacher teaches for a student to learn. And learning is aimed at bringing about a relatively positive permanent change. Where teaching activities that do not engender positive changes through the inculcation of the requisite knowledge are purported to be going on, systemic collapse is consciously or unconsciously nursed - this is the case of Nigeria. A recent United Nations Educational, Scientific and Cultural Organisation (UNESCO, 2014) report, which grouped Nigeria as one of the 37 countries in the world where learning has deserted schools, especially at the primary level, despite huge investments in education corroborates the author's opinion that what is going on in many Nigerian schools is teaching without learning. The UNESCO report is an alarming discomfiture that represents a new low in Nigerian education. At the $20^{\text {th }}$ Nigerian Economic Summit, which focused on education, the then Supervising Minister of Education, Nyesom Wike, mooted a similar concern when he said that the Federal Government had injected N7.97 trillion into education between 2009 and 2013, yet there are no signs of improvement. Before now, UNESCO's often-cited concern was the 10.5 million out-of-school children in Nigeria, the highest in the world. The Director-General of the global body, Irina Bokova, in the latest report released in January 2014, notably remarked in the foreword, "Access is not the only crisis-poor quality is holding back learning even for those who make it to school". This assertion is a reality in Nigerian context. During the launch of "Education For All, Global Monitoring Report" in Abuja, on January 29, 2014, UNESCO's Director in Nigeria, Hassana Alidou categorically stated that Nigeria has one of the worst education indicators globally.

Since 1999, the Federal Government has been using the Tertiary Education Trust Fund and the Universal Basic Education Commission as intervention platforms to funnel funds into primary, secondary and tertiary institutions, yet the decadence remains obvious with dilapidated learning facilities, unqualified teachers, explosion in school enrolment, laboratories without equipment, poor incentives for teachers and its attendant low morale. The Academic Staff Union of Universities (ASUU) has been at daggers' drawn with the Federal Government over the decay in the education sector. The situation is so appalling that no young person consciously takes to teaching as a career any longer.

At the primary level, the then Minister of Education, Professor Ruqayyatu Ahmed Rufai, identified 207, 818 unqualified teachers nationwide in 2010, with the North-East having the highest figure of 57.7 percent. Undoubtedly, the situation has deteriorated as the Boko Haram terror war has engendered the relocation of the 
few qualified teachers, and also forced both Federal and State Governments to close some schools in the area. The percentage spread of unqualified teachers in the nation is tabulated below:

\begin{tabular}{|l|c|}
\hline Geo-Political Zones & \% of Unqualified Teachers \\
\hline North-West & 46.8 \\
\hline North-Central & 38 \\
\hline South-South & 19.2 \\
\hline South-East & 16.7 \\
\hline South-West & 6.7 \\
\hline
\end{tabular}

Source: Punch, March, 2014

Endemic corruption in the education system: There is a worrisome diffusion of corruption into the education system from the larger Nigerian society. This increasingly embarrassing incidence of corruption in the system accounts for over 90 percent of the fundamental challenges that have bedevilled our education. The word 'corruption' in education system can be defined in broad terms to cover a wide range of misconducts including misuse of entrusted funds and power for private gain; theft; fraud; nepotism; abuse of power; examination malpractice which covers all forms of unconventional practices in taking examination, marking, grading and preparation of results; commercialization of admissions; sexual harassment; over use of power (such as observed in the intimidation and victimisation of students, delay and withholding of academic staff assessment, promotions and suppression of younger academic staff, etc); late submission and release of results, gangsterism; compelling students to buy handouts, lecture notes, textbooks and pegging their performance to it; cultism; dereliction of duty; use of undergraduates to mark examination scripts, prepare results and to do other sensitive jobs; embezzlement and diversion of funds; certificate forgery/racketeering; and poor supervision of students' work such as teaching practices, research project writing, industrial attachment programmes, fieldwork and laboratory practical.

Corrupt practices have unleashed enormous disastrous consequences on Nigeria's education system. For instance, corruption has negated the attainment of the beautiful educational objectives enunciated in the National Policy on Education (NPE, 1998; 2004). Nnodum (2008) noted that corruption has turned our institutions of learning into centres of moral decadence, crime propagation, lawlessness and social disintegration. Thus, standards both in academic performance, general conduct and behaviour have fallen ridiculously.

The pervasiveness of corruption in Nigeria's education system is such that cuts across all levels of the education system from the kindergarten level to the university level.

Certificate disease: The problem of certificate disease has to do with the excessive craze for certificates without interest in knowledge. Certificates have been ridiculously reduced to meal-tickets. Omatseye and Mogbeyiteren (2008) argued that in more recent times, the Nigerian educational system seems to be failing in its primary function of equipping learners with knowledge, abilities, attitudes and adequate skills because people are more conscious of acquiring certificates than knowledge. It is very sad to remark that emphasis has been shifted from the acquisition of knowledge to the award of certificates. This arguably explains why most products of Nigerian education who are superstars on paper end up performing terribly abysmally in their jobs. This ugly state of affairs is evident in the stupendous amount of resources employers of labour waste in retraining most Nigerian graduates so as to make them employable. This sorry development has seriously impacted negatively on the principles of professionalism. This is so because one does not necessarily have to study accounting, for instance, before one can work in the bank as the individual (whether a teacher, lawyer, doctor or engineer) would have to be retrained and given accounting skills. The outcome is that what an individual reads in the university rarely determines where he/she works.

Certificates are supposed to be the shadows, and knowledge the substance. But the reverse has become the case in Nigerian education system where people pursue certificates as the substance, and knowledge as the shadow. Some greenhorns in a Nigerian university on their matriculation day were asked how many of them would collect their certificates and leave the university if perhaps told that their certificates were ready on that particular day. A majority of them amazingly raised their hands. That was a grotesque manifestation of excessive quest for diplomas at the expense of the acquisition of the relevant skills and knowledge. Strategic steps and reforms should be made to urgently stop the tide of this embarrassing wave of such an anti-developmental attitude. The system should encourage the acquisition of knowledge and appropriate skills through the celebration of people with knowledge. Recruitment processes should be free, fair, credible and transparent enough to enable those with relevant knowledge have access to jobs. Situations where intellectually "empty" graduates secure lucrative jobs through political influence and sharp practice even without passing the interview for such jobs, whereas scholars and well-knowledgeable applicants who passed the interview are left out can discourage the hunger for the acquisition of knowledge. For instance, the researcher had had a very bitter experience when he emerged as one of the best interviewees for a Federal Government job and when the appointment letters came out, it was people who failed the very first stage of the interview and those who were 
not even shortlisted ab initio for the interview that were employed. The experience was discouraging and devastatingly frustrating. The researcher gave up with the faithful commitment to the pursuit of knowledge until the day he read a quote by Abraham Lincoln which encouraged the acquisition of knowledge principally for the power inherent in it and for the opportunities that will be attracted by it someday in life.

Hardly can anyone gainsay the fact that there are a lot of Nigerian graduates in possession of certificates they can hardly defend commendably because they lack relevant skills. Instead of helping to steer the nation towards democratic transformation and development, such half-baked graduates constitute nuisance in the society. Some get involved in high profile criminality. Recently, the operatives of the Special Anti-Robbery Squad (SARS) of Lagos State Police Command arrested a medical practitioner, a pastor, a musician and others for their alleged membership of a notorious armed robbery gang notable for terrorising banks in the South Western Nigeria. Among the allegations was their killing of three policemen last year November during an attack on Access Bank, Ayobo in Lagos, as well as in Ondo and Ogun States. The alleged involvement of a medical doctor in this notorious armed robbery gang is to all intents and purposes, a clear manifestation of the disastrous consequences of the possession of certificates without education. There is, therefore, a need to reform the system so that there will be a positive correlation between certificates and competences, such that qualifications will reflect competence.

Incessant strike actions: Incessant and disruptive industrial disharmony (between governments at all levels and workers at all levels of the Nigerian education) culminating in unnecessarily protracted strike actions have impacted negatively on the Nigerian education system. Strike is a deliberate and temporary stoppage of work in pursuance of a grievance or demand. Since its inception in 1978, the Academic Staff Union of Universities (ASUU) in Nigeria for instance, has embarked on over fifteen strikes. Nigerian university lecturers embarked on their first ever industrial action in 1973 under an umbrella body called the Nigerian Association of University Teachers (NAUT) which was formed in 1965. From 1990 till date, 1997, 1998 and 2004 were the only strikefree years in the academic history of Nigerian public universities. Between 1973 to 2010, Udom (2010) noted that Nigeria had accumulatively lost 4 years, 9 months and 3 weeks of academic sessions to strikes. At present (that is as 2019 when this paper was being written), ASUU has been on strike which started in November, 2018. The impacts of strike actions have always been profound and disruptive. Frequent shut down of schools leads to loss of time and consequent students' prolonged stay in school. Such protracted stay usually impact negatively on the finances of the students' sponsors, students' marital lives, their opportunities of getting jobs in the labour market especially these days that job adverts have age limit tags, and so on. Most disturbing of the devastating effects of incessant strike actions on the Nigerian educational system is the disruption of the educational curriculum. The time lost by students while their teachers are on strike, according to Oshun (2008), cannot simply be made up for as in a factory scenario by a speed-up in production. More often than not, in a bid to catch up with the school calendar, teachers on return from a strike attempt to cram several months' work of academic work in a few weeks in a bid to prepare the students for examinations. Some even skip certain contents of the curriculum. Thorough teaching and learning become subordinated to the completion of school calendar. Besides the negative implications of protracted strike actions in the Nigerian educational system, it also fuels a deluge of anti-social behaviour and social vices such as cultism, hooliganism, gangsterism, vandalism, armed robbery, terrorism, prostitution etc, because an idle mind, the saying goes, is the devil's workshop.

\section{Suggestions}

Entrepreneurial courses in higher institutions should be practical, instead of being theoretical. For instance, the most universities have business outfits like the sachet water manufacturing factories, printing press, furniture making centres, bakeries, catering services, etc. The theoretical entrepreneurship course offered in such universities can be restructured and made practical in orientation by allowing students to visit those centres to acquire skills on pure water manufacturing, printing of books, baking of bread, and so on. Even if this entails the extension of years of study by one year that will be invested in the acquisition of entrepreneurial skills, it is okay. It is better for our undergraduates to spend more years in school and when they graduate they become self-reliant and useful to the society than for them to spend few years and come out 'empty', unemployable and useless to the society throughout lifetime. Enough of theories in Nigerian education system! The education system should be drastically and radically reformed to make it practical in orientation, pragmatic and functional. Another way of achieving this is by establishing skills acquisition centres in tertiary institutions. Tertiary students should be given opportunities to acquire at least a skill before graduating from the higher institution. This will help to check the increasingly embarrassing menace of unemployment

The government should encourage private sector participation in the provision of quality education. Government alone cannot do it; therefore, there is the need to reinvigorate the private partnership programmes (PPP) of the former Minister of Education, Mrs Oby Ezekwesili. Government should not see private school owners as competitors but as partners with the same goal of providing quality education for national development. Therefore, pupils and students in private schools should also benefit from the free distribution of 
books and other learning materials from government at all levels. After all, some of the parents of these children in private schools are tax payers;

The government should urgently address infrastructural deficit particularly in poor postal system, erratic power supply, ICT spread and penetration, the digital divide and poor connectivity among tertiary institutions in the country that are essential for sharing of knowledge and quality education that will put the country on an upward developmental trajectory;

Radical reforms should be made to ensure that learning together with teaching goes on in Nigerian schools. Certificates should be de-emphasized. Appropriate skills and knowledge should be celebrated, and not certificates;

Members of the society should be enlightened and discouraged from worshipping paper certificates.

Government should wage a war against corruption in the education system. Reported cases of corrupt practices should be promptly treated and thoroughly investigated. Defaulters should be ruthlessly sanctioned or punished without fear or favour based on the stipulated penalty for the offences.

There should a closer link between the entire process of education and the world of work such that it would be possible for students to take a year or two off their academic programmes and acquire some practical job training/skills as is done in some Japanese and Chinese institutions;

There should be a broadened teacher education programme with the teaching practice period increased to a whole academic year instead of the present haphazard and hurriedly conducted teaching practice training and retraining system;

The whole world has gone digital with the advent of computer technology; therefore, computer training and the special skills in information technology (IT) should be made compulsory at all levels of schooling;

Technical education should be emphasized. More technical schools should be built and the existing ones revitalised;

Certain tertiary institutions should be designated as specialist centres of engineering, agriculture, medical sciences, computer science and other fields relevant to the priorities of national development;

\section{Conclusion}

The call for educational reforms is the call for change. Change, they say, is the only permanent thing in life. There is need for Nigeria to embrace positive educational changes that will put the products of Nigerian education system on the same pedestal with their counterparts abroad. Nigeria cannot afford to stand aloof to the trend in global educational advancement that will engender sustainable national development. We can only be seen to be serious with our quest for national development only if we take advantage of the whole new vistas opened by the limitless opportunities in quality education. Challenges besetting education in Nigeria such as teaching without learning in Nigerian schools, endemic corruption in the education system, certificate disease, incessant strike actions to mention but a few must be tackled holistically, immediately, vigorously and with evidence of seriousness and commitment.

\section{References}

Fafunwa, A.B. (2006). A keynote address presented at the Nigerian Association of Professional Education (NAPE) National Conference held from $25^{\text {th }}$ to $28^{\text {th }}$ October at the University of Lagos.

Federal Republic of Nigeria. (1998). National Policy on Education. Abuja, Federal Ministry of Education.

Federal Republic of Nigeria. (2004). National Policy on Education. Abuja, Federal Ministry of Education.

Maduka, C. (2008). Education and development; underlying issues: an introduction. In Maduka, C. and Afemikhe, O. A. (Eds). Issues in education, government and development. Nigeria: Amfitop.

Musa, C.N. and Ekwukoma, V. (2013).Teacher education programme in Nigeria : the need for a new paradigm. Journal of Education in Developing Areas, 21(1), 12-18.

Musa, C.N. and Musa, R.J. (2007). Education reforms for what? In Owan, A.O. (Ed). Education reforms in Nigeria. Nigeria: Saniez Books.

Nwadiani, M. And Otakhor, E.O. (2011). Determinants of doctorate degree programmes completion in Southern Nigerian Universities. African Journal of Studies in Education, 8(1\&2), 15-24.

Nnodum, B.I. (2008). Corrupt practices among academics as perceived by undergraduates: Implication for counselling and national development. International Journal of Educational Research, 4(1), 141-150.

Okeke, A.C.(1990), The Role of Educational Research in Enhancing the Participation of Women in National Development. Onitsha, Summer Educational Publisher.

Omatseye, B.O.J. and Mogbeyiteren, M. (2008). The certificate disease and productivity: the Nigerian dilemma. In Maduka, C. and Afemikhe, O. A. (Eds). Issues in education, government and development. Nigeria: Amfitop.

Osagie, R.O. and Ibadin, V.O.(2007). Quality assurance in secondary schools. African Journal of Studies in Education, 3(2), 123-132. 
Oshun, G.O.(2008). Perception of Effects of ASUU Strikes on the Undergraduate Students of Tertiary Institutions. In Maduka, C. and Afemikhe, O. A. (Eds). Issues in Education, Government and Development. Benin: Institute of Education, University of Benin. Pp 302-314.

Synomwene, A.(2013). Factors affecting teachers' implementation of curriculum reforms and educational policies in schools; Kenyan experience. Journal of Education and Practice, 4(22), 80-86.

Teaching Without Learning in Nigerian Schools. Sunday Punch, 30th March, 2014.

Udom, I. D. (2010). Impact of industrial disputes on the implementation of academic programmes in Nigerian universities (2000-2010). Unpublished PhD thesis, University of Benin, Benin City.

\section{Acknowledgement}

The authors are deeply indebted to the Nigerian Educational Research and Development Council (where the second author works) and the University of Benin, Benin City, Nigeria (where the $1^{\text {st }}$ and $3^{\text {rd }}$ authors work) for creating an enabling environment for quality theoretical and empirical research studies with enormous national and international benefits. The authors' colleagues who supported them in various ways in the course of writing this paper are greatly appreciated. Other authors whose works were consulted, cited and referenced in this paper are highly appreciated as well. 